\title{
Unusual suspects of secondary diabetes and growth retardation: Bartter and Gitelman syndrome
}

\author{
Zeynel Abidin Sayiner ${ }^{1}$, Burak Okyar ${ }^{2}$, Ayten Eraydin ${ }^{1}$, Mesut Ozkaya ${ }^{3}$
}

\begin{abstract}
Objective: Bartter syndrome and Gitelman syndrome are rare autosomal recessive syndromes. In extremely rare cases, GS may diagnosed with growth retardation and diabetes mellitus. In this 3-case series, growth retardation was identified at 17-year follow-up of our dizygotic twin patients diagnosed with BS and glucose metabolism disorder was developed. Whereas, 3rd. patient diagnosed with GS in adulthood period developed diabetes mellitus after 8 years follow up. Chronic hypopotassemia has been shown to cause diabetes mellitus and growth retardation in several articles. Potassium plays an important role in insulin, IGF-1 and growth hormone cycle. Herein, we aimed to draw attention to that, the presence of chronic hypopotassemia may precipitate to diseases such as growth retardation and diabetes mellitus over time.
\end{abstract}

Keywords: Bartter syndrome, Gitelman syndrome, Diabetes Mellitus

\section{Introduction}

Bartter syndrome (BS) and Gitelman syndrome (GS) are rare autosomal recessive (AR) syndromes $(1,2)$. These two syndromes are characterized with hypokalemia, metabolic alkalosis, hyperreninemia, hyperplasia in the juxtaglomerular apparatus and secondary hyperaldosteronism $(3,4,5,6)$. Bartter syndrome is often diagnosed before 6 years of life with clinical signs including polyuria, polydipsia, vomiting, constipation, salt cravings, growth retardation and fatigue. Some patients present growth and developmental delay (4-7-8-9). Whereas GS is usually diagnosed in the infancy period with similar symptoms, although it may diagnosed in late childhood, even in adulthood period depending on the type of genetic mutation (12). In extremely rare cases, GS may diagnose with growth retardation in an early age (10). Both diseases are characterized with hypopotassemia. In this 3-case series, growth retardation was identified at 17-year follow-up of our dizygotic twin patients diagnosed with BS and glucose metabolism disorder was developed. Whereas, our other patient diagnosed with GS in adulthood period developed diabetes mellitus (DM). Herein, we aimed to draw attention to that, the presence of chronic hypopotassemia may precipitate to diseases such as growth retardation and diabetes mellitus over time

\section{Cases}

\section{Case 1:}

First of the twins was examined due to vomiting, polyuria, polydipsia, dehydration, weight loss and growth retardation beginning from the birth. Height and weight of the patient were below the 3rd percentile. Laboratory tests revealed potassium $(\mathrm{K})$ : $2.04 \mathrm{mmol} / \mathrm{L}$, sodium $(\mathrm{Na}): 142 \mathrm{mmol} / \mathrm{l}$, calcium $(\mathrm{Ca})$ : $8.8 \mathrm{mg} / \mathrm{dl}$, magnesium $(\mathrm{Mg}): 1.56 \mathrm{mg} / \mathrm{dl}$ and chlorine (Cl): $95 \mathrm{mmol} / \mathrm{l}$. In the venous blood gas, $\mathrm{pH}$ was 7.60, HCO3: $38.9 \mathrm{mmol} / \mathrm{l}$ and pCO2: $30.2 \mathrm{mmHg}$ (3248). Upon the patient was diagnosed with hypokalemic, hypochloremic metabolic alkalosis, additional studies were carried out. Aldesterone was found as $1933.2 \mathrm{pg} / \mathrm{ml}(35-410)$ and Angiotensin-1 as $19 \mathrm{ng} / \mathrm{ml}$ (1.5-5.5). Since the patient who was diagnosed with Bartter syndrome when he was 11month-old developed growth and developmental retardation from the birth, IGF-1 was examined and found as $38.3 \mathrm{ng} / \mathrm{mL}$ (288-736). He had no familial history of growth retardation. The patient who was diagnosed with growth retardation secondary to Bartter syndrome was put on recombinant human growth hormone therapy. At follow-ups of the patient; upon routine outpatient clinic measurements performed at 18-year-old yielded K:2.4 mmol/1, Cl: 94 $\mathrm{mmol} / \mathrm{L}$ and spontaneous blood glucose: $120 \mathrm{mg} / \mathrm{dl}$,

Received 15-02-2017 Accepted 24-02-2017 Available Online 28-02-2017

1 Gaziantep University, Faculty of Medicine, Dept. of Endocrinology\&Metabolism, Gaziantep, TR

2 Gaziantep University, Faculty of Medicine, Dept. of İnternal Medicine, Gaziantep, TR

3 Gaziantep Dr. Ersin Arslan Research Hospital, Dept. of Endocrinology\&Metabolism Gaziantep, TR

* Corresponding Author: Zeynel Abidin Sayiner E-mail: zeynelasayiner@hotmail.com Phone: +90 3423606060

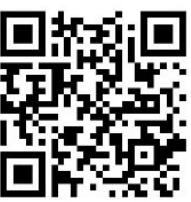


the patient underwent $75 \mathrm{~g}$ glucose tolerance test. The patient with second hour blood glucose: $138 \mathrm{mg} / \mathrm{dl}$ and HgbA1c: $6.4 \%$ was diagnosed with impaired fasting glucose.

\section{Case 2:}

The second twin was examined for the complaints of vomiting, polyuria, polydipsia, dehydration, weight loss and growth retardation beginning from the birth. Likewise the other twin, this patient was also below the 3rd percentile in height and weight. Laboratory tests revealed $\mathrm{K}: 1.46 \mathrm{mmol} / \mathrm{l}$, Na: $131 \mathrm{mmol} / \mathrm{l}, \mathrm{Mg}$ : $1.7 \mathrm{mg} / \mathrm{dL}, \mathrm{Cl}: 92 \mathrm{mmol} / \mathrm{l}$ and $\mathrm{Ca}: 9.5 \mathrm{mg} / \mathrm{dl}$, while blood gas showed pH: 7.57, HCO3: $30.2 \mathrm{mmol} / \mathrm{l}$ and pCO2: $22.3 \mathrm{mmHg}$. The patient's Aldesterone was $>2000 \mathrm{pg} / \mathrm{ml}$ and Angiotensin-1: $>9 \mathrm{ng} / \mathrm{ml}$ and similarly to the other twin, the patient was diagnosed with Bartter syndrome when he was 11-month-old. Upon the patient developed growth retardation, ordered GH was found as $0.068 \mathrm{ng} / \mathrm{ml}(0.14-15.7)$ and IGF-1 as $39.7 \mathrm{ng} / \mathrm{ml}(288-736)$. The patient was diagnosed with growth hormone deficiency secondary to Bartter syndrome and recombinant human growth hormone therapy was initiated. Blood tests at routine outpatient examination of the patient carried out at 18year-old revealed Na: $137 \mathrm{mmol} / \mathrm{l}, \mathrm{K}: 2.4 \mathrm{mmol} / \mathrm{l}, \mathrm{Cl}$ : $93 \mathrm{mmol} / \mathrm{l}$ and spontaneous fasting blood glucose: 165 $\mathrm{mg} / \mathrm{dl}$.
Hereupon the patient underwent $75 \mathrm{~g}$ OGTT. Upon the second hour blood glucose was $142 \mathrm{mg} / \mathrm{dl}$ and Hemoglobin A1c was $6.3 \%$, diagnosis of diabetes mellitus was established.

Case 3:

A 40-year-old female patient was examined upon the routine study revealed $\mathrm{Mg}: 1.2 \mathrm{mg} / \mathrm{dll}$ and $\mathrm{K}: 2.8$ mmol/1. Blood gas analysis showed $\mathrm{pH}$ : 7.49, pCO2: $38 \mathrm{mmHg}$, and HCO3: $32 \mathrm{mEq} / \mathrm{l}$ in the patient who was then diagnosed with Gitelman syndrome with nephrocalcinosis found on the plain renal radiography ordered and daily urinary calcium below $50 \mathrm{mg}$ /day. In gene analysis, SCL12A3 homozygous gene defect was identified and the patient was taken under followup and treatment. Upon at follow-ups the patient developed polyuria and polydipsia symptoms, her spontaneous blood glucose was measured and found as $140 \mathrm{mg} / \mathrm{dl}$, therefore she underwent oral glucose tolerance test. Upon the second hour blood glucose was above $200 \mathrm{mg} / \mathrm{dl}$ and HgbAlc was found as 7.2, the patient was diagnosed with diabetes mellitus. The patient had no familial history. Her body mass index was under $25 \mathrm{~kg} / \mathrm{m} 2$. She had also no a history of gestational diabetes mellitus. The patient was taken under follow-up and treatment with the diagnosis of diabetes mellitus secondary to Gitelman syndrome.

Table 1: Characteristics of the patients at 9 months old

\begin{tabular}{lll} 
& \multicolumn{1}{c}{ TWIN 1 } & \multicolumn{1}{c}{ TWIN 2 } \\
\hline & At 9-month-old & At 9-month-old \\
$\mathbf{N a}$ & $142 \mathrm{mmol} / 1$ & $131 \mathrm{mmol} / 1$ \\
$\mathbf{K}$ & $2.04 \mathrm{mmol} / 1$ & $1.46 \mathrm{mmol} / 1$ \\
$\mathbf{C l}$ & $95 \mathrm{mmol} / 1$ & $92 \mathrm{mmol} / 1$ \\
$\mathbf{C a}$ & $8.8 \mathrm{mg} / \mathrm{dl}$ & $9.5 \mathrm{mg} / \mathrm{dl}$ \\
$\mathbf{M g}$ & $1.56 \mathrm{mg} / \mathrm{dl}$ & $1.7 \mathrm{mg} / \mathrm{dl}$ \\
Blood gas Ph & 7,60 & 7,59 \\
Blood gas HCO3 & $38.9 \mathrm{mmol} / 1$ & $44 \mathrm{mmol} / 1$ \\
IGF-1 & $38.3 \mathrm{ng} / \mathrm{ml}$ & $39.7 \mathrm{ng} / \mathrm{ml}$ \\
Growth Hormon & $0.13 \mathrm{ng} / \mathrm{ml}$ & 0.06 \\
Aldesterone & $1933.2 \mathrm{pg} / \mathrm{ml}$ & $>2000 \mathrm{pg} / \mathrm{ml}$ \\
Angiotensin-1 & $19 \mathrm{ng} / \mathrm{ml}$ & $>9 \mathrm{ng} / \mathrm{ml}$ \\
\hline
\end{tabular}

Table 2: Characteristics of the patients at 18 years old

TWIN 1

At 18-year-old

Na

K

Cl

Fasting Blood Glucose

75 gr OGTT, $2^{\text {nd }}$ hour

HgbA1c
$138 \mathrm{mmol} / 1$

$2.4 \mathrm{mmol} / 1$

$94 \mathrm{mmol} / \mathrm{l}$

$120 \mathrm{mg} / \mathrm{dl}$

$138 \mathrm{mg} / \mathrm{dl}$

$6.4 \%$
TWIN 2

At 18-year-old

$137 \mathrm{mmol} / 1$

$2.4 \mathrm{mmol} / 1$

$93 \mathrm{mmol} / 1$

$165 \mathrm{mg} / \mathrm{dl}$

$142 \mathrm{mg} / \mathrm{dl}$ $6.3 \%$ 


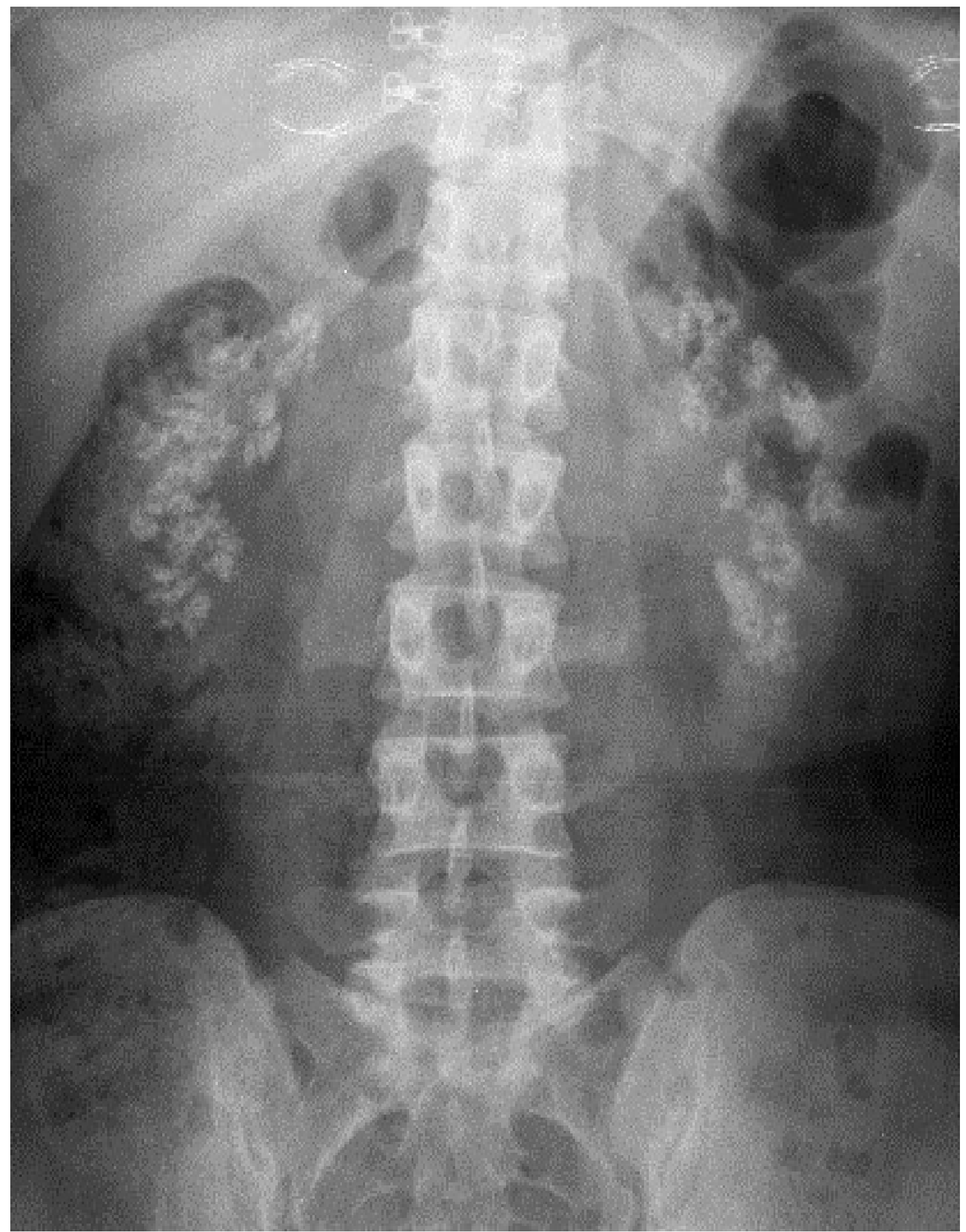

Image 1: Direct X-ray graph of Renal Nephrocalcinosis in the patient with Gitelman syndrome

\section{Discussion}

Studies have shown that chronic hypokalemia leads to disruption in the secretion of growth hormone and insulin. In diseases progressing with hypokalemia such as Bartter syndrome, resistance develops against growth hormone, insulin and IGF-1 hormone at receptor level. Studies performed have demonstrated that in prolonged hypopotassemia IGF-1, insulin and $\mathrm{GH}$ cause alterations in the level of mRNA from which they were cloned (11-12-13-14). 
In a study conducted on rats, hypopotassemia has been shown to create changes in transcription of the gene coding these hormones and its product mRNA with an unknown mechanism, reducing the number of receptors (12).

Insulin release occurs as a result of the opening of $\mathrm{Ca}$ channel, entering into the cell following the closure of K-ATPase channels and hyperpolarization (16).

$\mathrm{K}+$ channel which remain open causes the leakage of $\mathrm{K}+$ from inside to outside of the cell and hyperpolarization cannot occur in this case. Chronic hypopotassemia may cause suppression of hyperpolarization by change of the intra- and extracellular electrical gradient. In addition, decreased amount of extracellular $\mathrm{K}+$ may cause a continuous leakage of $\mathrm{K}+$ from inside to outside of the cell. This mechanism may lead to the development of insulin resistance. In a study, 16 patients diagnosed with GS underwent OGTT after a mean follow-up duration of 11 years.

Six of these patients were diagnosed with overt diabetes mellitus, while 2 patients were diagnosed with isolated glucose tolerance and 2 patients with impaired fasting glucose. In the tests performed in our patients; impaired glucose metabolism was identified in both twin patients after a 17-year follow-up, while the other patient with GS was diagnosed with overt diabetes mellitus after a 8-year follow-up and the secondary causes were ruled out (15).

All these studies indicate that hypopotassemia has a crucial place in growth hormone and insulin hormone cycles. In our case, the levels of IGF-1 and GH were decreased despite treatment continued until 18-yearold in the twin patient with chronic hypokalemia who was diagnosed with Bartter syndrome 11 months after the birth, height and weight were below the 3rd percentile and both twins developed impaired glucose metabolism in the progressing course, supporting these theories.

Although its mechanism of action is yet to be fully understood, chronic hypopotassemia has been shown to disrupt insulin and glucose regulation. In conclusion potassium plays an important role in insulin, IGF-1 and growth hormone cycle. However, it is still not clear the place of potassium in this hormonal cycle mechanism. Further new studies at molecular level are needed in order to clarify this issue.

Conflict of Interest: The authors declare no potential conflicts of interest with respect to the research, authorship, and/or publication of this article.
Acknowledgement: Author Contributions: ZAS, BO, AE, MO: Examination of patients, Diagnosis of syndromes, writing of article, ZAS Editing of Article.

Ethical issues: All Authors declare that Originality of research/article etc... and ethical approval of research, and responsibilities of research against local ethics commission are under the Authors responsibilities. The study was conducted due to defined rules by the Local Ethics Commission guidelines and audits.

\section{References}

1. Kurtz I. Moleculer pathogenesis of Bartter's syndromes. Kidney Int 1998; 54:1396.

2. Simon DB, Nelson-Williams C, Bia MJ, et al. Gitelman's variant of Bartter's syndrome, inherited hypokakaemic alkalosis, is caused by mutations in the thiazide-sensitive $\mathrm{Na}-\mathrm{Cl}$ cotransporter. Nat Genet 1996; 12:24.

3. Monnens L, Bındels R, Grünfeld JP. Gitelman syndrome comes of age. Nephrol Dial Transplant 1998; 13:1617

4. Bettinelli A, Bianchetti MG, Girardin E, et al. Use of calcium excretion values ti distinguish two forms of primary renal tubuler hypokalemic alkalosis: Bartter and Gitelman syndromes. J Pediatr 1992; 120:38.

5. Cruz DN, Shaer AJ, Bia MJ, et al. Gitelman's syndrome revisited: an evaluation of symptoms and health related quality of life. Kidney Int 2001;59:710.

6. Cruz DN, Simon DB, Nelson-Williams C, et al. Mutations in the $\mathrm{Na}-\mathrm{Cl}$ cotransporter reduce blood pressure in humans. Hypertension 2001; 37:1458.

7. Stein JH. The pathogenetic spectrum of Bartter's syndrome. Kidney Int 1985; 28:85.

8. Sann L, David L, Bernheim J, François R. Hypophosphatemia and hyperparathyroidism in a case of Bartter's syndrome. Helv Pediatr Acta 1978; 33:299

9. Bettinelli A, Vigano C, Provero MC, et al. Phosphate homeostasis in Bartter syndrome: a case-control study. Pediatr Nephrol 2014; 29:2133.

10. Riveira-Munoz E, Chang Q, Godefroid N, et al. Transcriptional and functional analyses of SLC12A3 mutations: new ckues for the pathogenesis of Gitelman syndrome. J Am Soc Nephrol 2007; 18:1271.

11. Flyvbjerg A, Dorup I, Everts ME, Orskow H. Evidence that potassium deficiency induces growth retardation through reduced circulating levels of growth hormone ad insulin like growth factor I. Metabolism 1991;40:769-75.

12. Gil-Pena H, Garcia-Lopez E, Alvares-Garcia O, Loredo V, Carbajo-Perez E, Ordonez FA, et al. Alterations of growth plate and abnormal insulin-like growth factor I metabolism in growth hormone treatment. Am J Physiol Renal Phsiol 2009;297:F639-45. 
13. Ruvalcaba RH, Martinez FE. Case report: familial growth hormone deficiency associated with Bartter's syndrome. Am J Med Sci 1992;303:411-4.

14. Buyukcelik M, Keskin M, Kilic BD, Kor Y, Balat A, Bartter syndrome and growth hormone deficiency: three cases. Pediatr Nephrol 2012;27:2145-8.
15. Hong R, Ling Q, WeiMing W, Jun M, Wen Z, Ping YS, Hao S, Xiao L, Nan C. Abnormal Glucose Metabolism and Insulin Sensivity in Chinese Patients with Gitelman Syndrome. Am J Nephrol 2013;37:152-157.

16. Xu S, Kim JH, Hwang KH, Das R, Quan X, Nguyen TT, Kim SJ, Cha SK, Park KS. Autocrine İnsulin İncreases plasma membrane K(ATP) channel via PI3K-VAMP2 pathway in MIN6 cells. Biochem Biophys Res Commun. 2015 Dec 25;468(4):752-7.

Copyright (C) 2016 The Author(s); This is an open-access article distributed under the terms of the Creative Commons Attribution License (http://creativecommons.org/licenses/by/4.0), which permits unrestricted use, distribution, and reproduction in any medium, provided the original work is properly cited. All Rights reserved by international journal of Medical Science and Discovery. 